\title{
The Application of Industrial Endoscope to Observation of the Ocular-fundus in Small Laboratory Animals
}

\author{
Iwami KIYOSAWA, Norisato ARUGA, Masatomo KAWAKUBO, \\ Jun NAITO, Toru R. SAITO*, and Kazuaki W. TAKAHASHI* \\ Kissei Pharmaceutical Co., Ltd., 2320-1 Maki, Hotaka, Minamiazumi-gun, \\ Nagano 399-83 and * Department of Laboratory Animal Science, \\ Nippon Veterinary and Animal Science University, 1-7-1 \\ Kyonan, Musashino-shi, Tokyo 180, Japan
}

(Received 10 June 1991/Accepted 30 July 1991)

\begin{abstract}
Observation and recording methods of the ocular-fundus in small laboratory animals were studied using the industrial endoscope and VTR systems, respectively. The ocular-fundus was observed widely, brightly and clearly in the usual animal facility. In addition, the ocular-fundus was recorded easily and it was possible to examine the ocular-fundus recorded by the VTR systems. - KEY WORDS : endoscope, ocular-fundus, rodents
\end{abstract}

\section{実験用小動物眼底検査に打ける工業用内視鏡の応用}

清澤岩水·有賀憲鄉・ 川久保雅友・内藤 惇

斎藤徹*高橋和明*

キッセイ薬品工業株式会社

*日本獣医畜産大学実験動物学教室

近年, 毒性学を始めとする医学・獣医学等の臨床医学 の分野では一般臨床検查に加えて, 特殊検査としての眼 検査の重要性が認められている。眼検査の中で主要な位 置を占めている眼底検査では, 検眼鏡または眼底カメラ を使用した眼底 (網膜, 視神経乳頭, 脈絡膜の一部) の 観察・記録・検討が一般に行われている方法である。今 回, 我々は工業用硬性鏡を利用した実験用小動物眼底の 観察方法とカメラおよびビデオデッキを用いた記録方法 について検討したので報告する。

I : 写真撮影用システム機器 (オリンパス光学)

·工業用硬性鏡；OLYMPUS F 055-029-000-55

外径 $5.53 \mathrm{~mm}$

有効長 $290 \mathrm{~mm}$

\author{
視野方向 直視 $0^{\circ}$ \\ 視野角 $55^{\circ}$ \\ 観察深度 $5 \mathrm{~mm} \sim \infty$
}

·光源装置; OLYMPUS ILV

・内視鏡用カメラ; OLYMPUS SC-35

・アダプター; OLYMPUS SM-R

工業用硬性鏡, 光源装置, アダプターおよび内視鏡用 カメラをFigs. 1，2のようにセットした。散瞳㓮（参 天製薬, ミドリンP）にて散瞳させた動物を保定した 後, 眼底の観察・検討と写真撮影を行った。

II：ビデオ撮影用システム(オリンパス光学)

・工業用硬性鏡；OLYMPUS F 055-029-000-55 


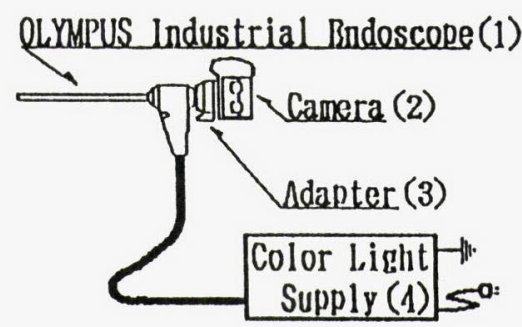

Fig. 1. Photographic System

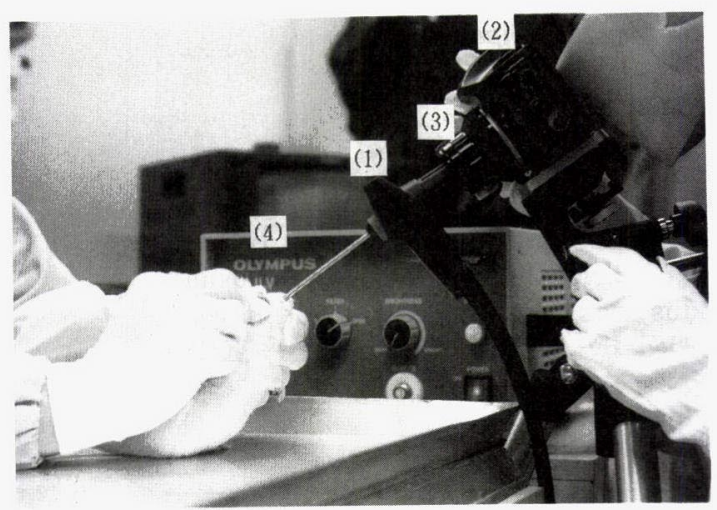

Fig. 2. Examination and Photograph

- 光源装置; OLYMPUS ILV

・カメラ装置; OLYMPUS IKEGAMI FCD725

・アダプター; OLYMPUS MC-R 44

. $€=$ タ - ; OLYMPUS FCM-145

工業用硬性鏡, 光源装置, アダプター, カメラ装置お よびモニターをFigs. 3，4のよらにセットした。散 瞳剤（ミドリンP）にて散瞳させた動物を保定した後, 眼底の観察・検討とビデオ撮影を行った。

本写真撮影用システムによりマウス, ラット扎よびス ナネズミ等の眼底は鮮明に観察できた。Fig. 5 に写真 撮影用システムにて撮影した Sprague-Dawley 系ラッ トの正常眼底の写真を示した。本システムにて撮影され た写真は眼底が広範囲に撮影されており, 焼付加減で明 るさがある程度加减できる。視神経乳頭や動静脈等も鮮 明であり，眼底所見を検討するのに充分な写真であると 思われる。

Fig. 6 にICR 系マウス (アルビノ), Fig. 7 に DA 系ラット（有色）の眼底写真をそれぞれ示した。

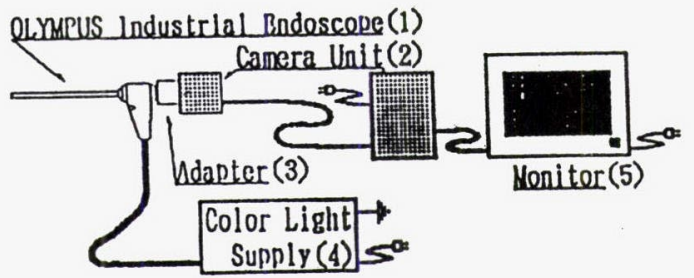

Fig. 3. Video System

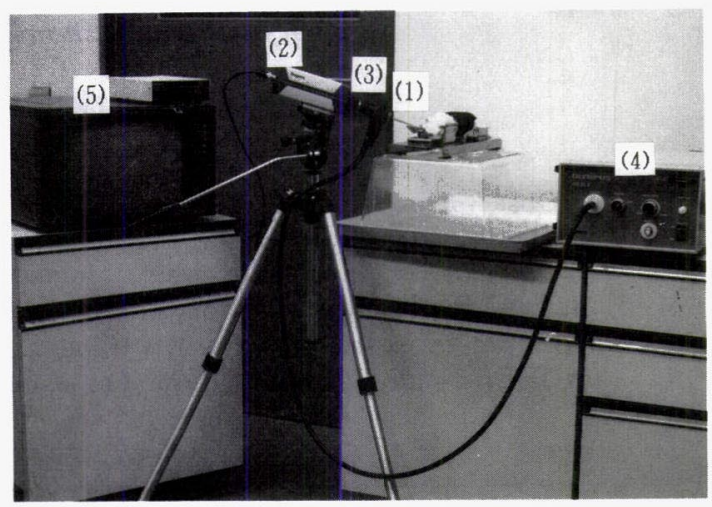

Fig. 4. Video System

写真撮影用システムにて撮影したスナネズミの蛍光眼 底写真を Fig. 8 に示した。励起用フィルターとして, 青フィルター B-480（ケンコー）を, 濾過用フィルタ ーとして, 20Y 495-W22 (オリンパス光学) を使用し, 診断用フルオレスチン液 $10 \mathrm{~W} / \mathrm{V} \%$ (小林製薬) の 1.2 $\mathrm{ml} / \mathrm{kg}$ を静脈内に投与して撮影した。

各写真撮影時の条件を Table 1 に示した。

写真撮影用システムを用いた観察・撮影の大きな利点 は, 現在, 汎用されている手持ち式眼底カメラ（コーワ $\mathrm{RC}-2$, 小動物用, 倍率 1 ) に比較して広範囲な眼底が 観察出来ることや, 光量が豊かな為に明るい動物室内で もそのまま使用できる事があげられる。欠点として, こ の装置は本来の眼底観察用内視鏡でないので, 手持ち式 眼底カメラよりも視野は広いが, 眼底像は内視鏡の口径 に依存する為にその像は小さく観察される。その為に, 通常の写真にプリントする時には拡大することが必要で ある。また，蛍光眼底撮影については常に同一光量であ る（ストロボ装置ではない）ために, 小血管の解像度に 問題があると思われる。著者らはスナネズミで手持ち式 
Table 1. Photographic condition of the ocular-fundus by the industrial endoscope system (Olympus Co., Ltd.)

\begin{tabular}{|c|c|c|c|c|c|}
\hline \multirow{2}{*}{$\begin{array}{l}\text { ANIMAL } \\
\text { (Strain) }\end{array}$} & \multirow{2}{*}{$\begin{array}{l}\text { Fundus } \\
\text { Photography }\end{array}$} & \multirow{2}{*}{$\begin{array}{l}\text { FILM } \\
\text { (ISO) }\end{array}$} & \multirow{2}{*}{$\frac{\text { LIGHT SUPPLY }}{\text { Lightness }(/ 300 W)}$} & \multicolumn{2}{|c|}{ CAMERA for ENDOSCOPE } \\
\hline & & & & Shutter-setting & Correct-exposure \\
\hline $\begin{array}{l}\text { MOUSE } \\
\text { (Slc:ICR) }\end{array}$ & Regular & $400 / 27^{\circ}$ & 150 & $1 / 60$ & -3.5 \\
\hline $\begin{array}{l}\text { RAT } \\
\text { (Slc:Sprague-Dawley) }\end{array}$ & Regular & $400 / 27^{\circ}$ & 150 & $1 / 60$ & -3.5 \\
\hline $\begin{array}{l}\text { RAT } \\
\text { (DA/Slc) }\end{array}$ & Regular & $400 / 27^{\circ}$ & 200 & $1 / 60$ & -4.0 \\
\hline $\begin{array}{l}\text { Mongolian } \\
\text { gerbil/Sea }\end{array}$ & Fluorescein & $1600 / 33^{\circ}$ & 300 & $1 / 15$ & -4.0 \\
\hline
\end{tabular}

眼底カメラの撮影時に用いる $1.0 \mathrm{ml} / \mathrm{kg}$ フルオレスチ ン量から $1.5 \mathrm{ml} / \mathrm{kg}$ 同量まで試みてみたが, 著しい差 異はみられなかった。

ビデオ撮影用システムを用いると光量が豊かな為, 眼 底は鮮明に観察され，容易に記録することができる。こ の眼底の経時的記録は複数の研究者による検討にも利用 でき，極めて有効に活用出来る。さらに，ビデオプリン ターを用いればその時々の眼底を写真の形で記録できる。

ビデオ撮影用システムを用いた蛍光眼底は, 白黒画像 において, 普通眼底で観察出来る中〜大血管の撮影は可 能であったが，小血管の解像は現段階ではまだ悪く，鮮 明な観察・記録はできなかった。

以上より，本装置システムは非常に簡便に実験用小動 物の眼底検查に有効活用できるものと思われる。眼底検 査専用機種として内視鏡の長さの短い機種があれば, 更 に操作性や観察能は向上すると思われる。また, 蛍光眼 底の為の光源としてストロボ装置等の併用が可能ならば 更に解像度は向上するものと考えられる。

\section{要約}

内視鏡を利用した実験用小動物の眼底観察方法とカメ ラおよびビデオデッキを用いた記録方法について検討し た。通常の動物飼育室内で, 広角度の眼底が明るく, 鮮 明に観察できた。また，カメラおよびビデオを用いた記 録も容易であり，記録された眼底像の検討も可能であっ た。

稿を終わるにあたり御協力いただいた株式会社オリンパスの 柳沢 弘, 松本 悟両氏に感謝いたします。

\section{文嗝}

［1］高橋和明 - 斎藤 徹 -三森国敏 - 田内清憲，(1980）、視 覚障害検査法. 蒋物と感覚障害, P 20-51, 中島 章. 秋吉正豊編, ソフトサイェンス社, 東京.

[2]今道友則 (研究代表者)（1983）。各種実験動物の眼底検 査法の開発・研究. 昭和57年度科学研究費補助金（一般 研究B）研究成果報告書.

\section{Explanation of Figures}

Fig. 5. Ocular-fundus photograph (Rat, Slc: S D)

Fig. 6. Ocular-fundus photograph (Mouse, Slc : I $\mathrm{CR})$
Fig. 7. Ocular-fundus photograph (Rat, DA/Slc)

Fig. 8. Fluorescein ocular-fundus photograph (Mongolian gerbil/Sea) 

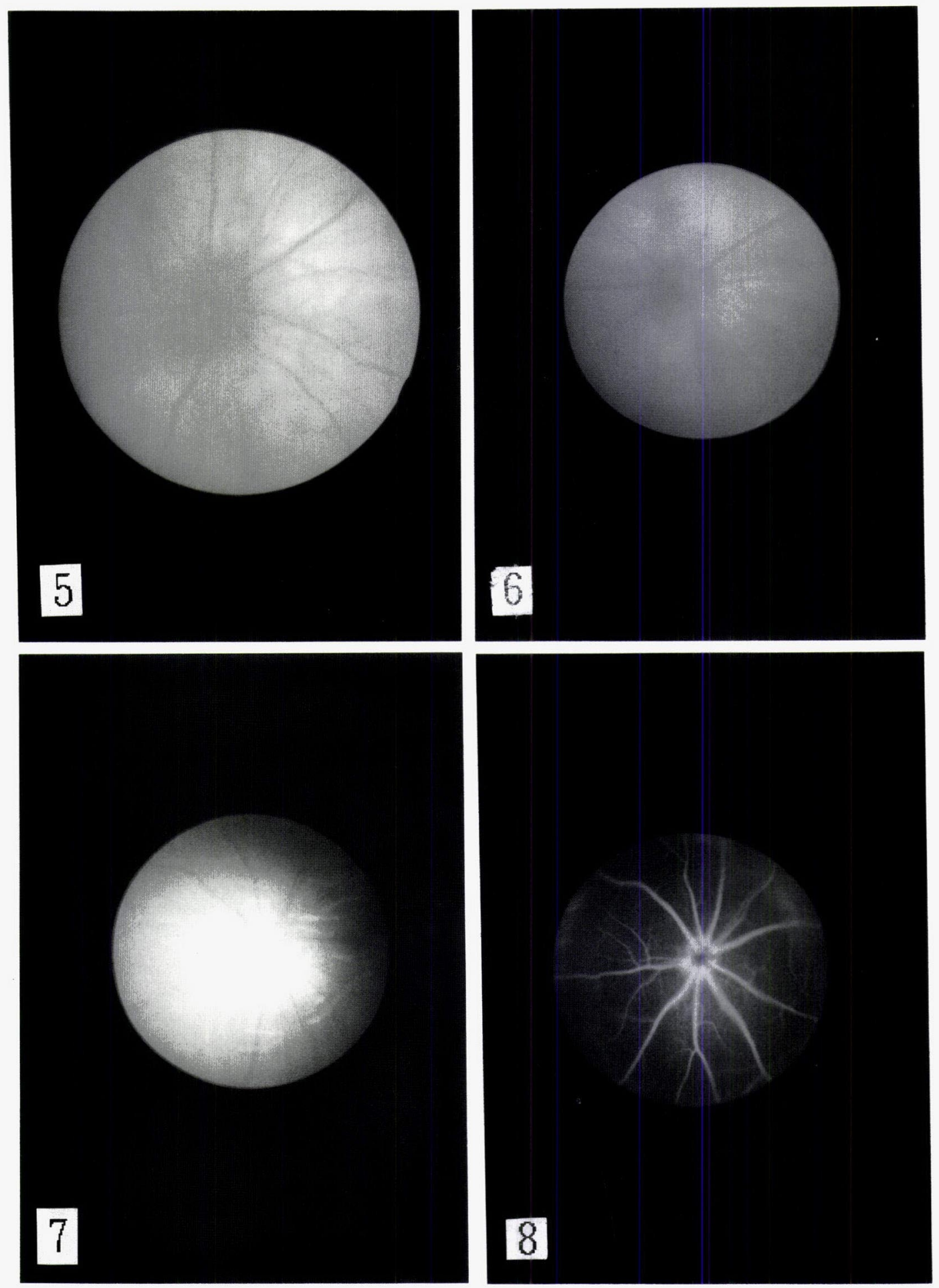